\title{
STRATEGI CAMPAIGN MELALUI SENI CAMPURSARI "SISWO LARAS BUDOYO" SEBAGAI UPAYA MENGEMBANGKAN \\ KEPEDULIAN MASYARAKAT BAGI PENDIDIKAN KHUSUS DI KABUPATEN BOJONEGORO
}

\author{
Sutras \\ Kepala SLB Negeri Kalirejo. Bojonegoro \\ sutrassartus@gmail.com
}

\begin{abstract}
Abstrak
Kepedulian masyarakat terhadap pentingnya pendidikan harus terus ditingkatkan termasuk kepedulian pendidikan bagi Anak Berkebutuhan Khusus. Persepsi negative masyarakat terhadap kemampuan Anak Berkebutuhan Khusus juga harus dirubah menjadi persepsi yang positif sehingga anak berkebutuhan khusus mempunyai kesempatan untuk meningkatkan kompetensi dirinya. Tujuan penelitian "Strategi Campaign Melalui Seni Campursari "Siswo Laras Budoyo" Sebagai Upaya Mengembangkan Kepedulian Masyarakat Bagi Pendidikan Khusus di kabupaten Bojonegoro" untuk, 1) meningkatkan kepedulian masyarakat terhadap pentingnya sekolah bagi ABK, 2) meningkatkan kepercayaan masyarakat terhadap kualitas SLB Negeri Kalirejo. Kegiatan dilakukan mulai bulan Oktober tahun 2018 sampai Januari 2019 di empat kecamatan yaitu Ngraho, Margomulyo, Tambakrejo, dan Ngambon. Hasil dari kegiatan ini adalah 1) Peningkatan kepedulian masyarakat terhadap pentingnya sekolah bagi anak berkebutuhan khusus, sebelumnya 12 responden meningkat menjadi 36 responden sehingga ada peningkatan dua kali lipat dan tercatat 13 pendaftar calon peserta didik baru tahun pelajaran 2019/2020,2) Peningkatan kepercayaan masyarakat terhadap kualitas SLBN Kalirejo, sebelumnya 12 responden meningkat menjadi 30 responden sehingga ada peningkatan sekitar 1,5 kali lipat.
\end{abstract}

Kata kunci : Kompetensi Manajerial, Strategi Campaign, Seni Campursari

\begin{abstract}
Public awareness of the importance of education must continue to be increased including education care for Children with Special Needs. The negative public perception of the ability of Children with Special Needs must also be changed to a positive perception so that children with special needs have the opportunity to improve their competence. The purpose of research "Campaign Strategy through the Art of Campursari" Siswo Laras Budoyo "As an Effort to Develop Community Awareness for Special Education in Bojonegoro District" 1) increase public awareness of the importance of schools for special needs students, 2) increase public confidence in the quality of Kalirejo State SLB. Activities will be carried out from October 2018 to January 2019 in four districts namely Ngraho, Margomulyo, Tambakrejo, and Ngambon. The results of this activity are 1) Increased public awareness of the importance of schools for children with special needs, previously 12 respondents increased to 36 respondents so there was an increase doubled and recorded 13 registrants of new student candidates for the 2019/2020 school year, 2) Increased public confidence in the quality of Kalirejo SLBN, previously 12 respondents increased to 30 respondents so there was an increase of about 1.5 times.
\end{abstract}

Keywords: Managerial Competence, Campaign Strategy, Art of Campursari 
Strategi Campaign Melalui Seni Campursari "Siswo Laras Budoyo" Sebagai Upaya Mengembangkan

Kepedulian Masyarakat Bagi Pendidikan Khusus Di Kabupaten Bojonegoro

Sutras

\section{PENDAHULUAN}

Kepedulian masyarakat Indonesia masih rendah terhadap pentingnya pendidikan bagi Anak Berkebutuhan Khusus. Secara nasional dari 1,6 juta Anak Berkebutuhan Khusus, 18 persen sudah mendapatkan layanan pendidikan inklusi, 115 ribu bersekolah di SLB, sedangkan yang bersekolah di sekolah reguler terdekat berjumlah sekitar 299 ribu.

Di kabupaten Bojonegoro secara umum kepedulian orang tua masih rendah terhadap pendidikan Anak Berkebutuhan Khusus. Data dinas pendidikan kabupaten Bojonegoro tahun 2017 jumlah anak berkebutuhan khusus yang belum mendapatkan layanan pendidikan masih tinggi sampai pada kisaran 60\% atau sekitar 1250 anak dari jumlah Anak Berkebutuhan Khusus. Sedangkan Anak Berkebutuhan Khusus yang sekolah di SLB sekitar 732 dan selebihnya mendapatkan layanan pendidikan di sekolah inklusi (sumber: MKKS PK Bojonegoro).

Di wilayah terdekat SLB Negeri Kalirejo yaitu kecamatan Ngraho, Margomulyo, Tambakrejo, dan Ngambon yang menjadi faktor penyebab minimnya jumlah Anak Berkebutuhan Khusus bersekolah adalah, 1) stigma orang tua belum sepenuhnya bisa menerima keberadaan ABK, 2) persepsi masyarakat bahwa ABK tidak mampu dan tidak perlu sekolah, 3) belum ada bukti karya nyata siswa SLB, dan 4) rendahnya kepercayaan masyarakat terhadap lembaga pendidikan yang dapat memandirikan ABK.

Sebagai kepala sekolah yang harus melaksanakan lima kompetensi yaitu kompetensi kepribadian, manajerial, sosial, supervisi, dan kewirausahaan. Dalam mewujudkan kompetensi manajerial dan sosial maka semenjak dilantik kami melaksanakan sosialisasi keberadaan SLB Negeri Kalirejo dengan kegiatan menyebar pamlet, siaran radio, pendataan langsung ke desa, dan kunjungan ke rumah-rumah anak berkebutuhan khusus. Namun hasil kegiatan ini tidak maksimal terbukti jumlah ABK yang mendaftar ke sekolah masih rendah. Rata-rata peserta didik baru di SLB Negeri Kalirejo tiap tahun berkisar 2 sampai 3 anak berkebutuhan khusus.

Selanjutnya penulis melakukan survey pendapat masyarakat tentang keberadaan SLBN Kalirejo di 6 desa dengan 60 responden, hasilnya hanya 20\% atau 12 orang yang percaya pentingnya sekolah bagi anak berkebutuhan khusus, $10 \%$ atau 6 orang percaya terhadap baiknya kualitas layanan pendidikan di SLBN Kalirejo. Jumlah ini sangat kecil sehingga perlu strategi baru yang dapat meningkatkan kepedulian masyarakat terhadap pentingnya sekolah bagi anak berkebutuhan khusus serta untuk meningkatkan kepercayaan masyarakat terhadap kualitas SLB Negeri Kalirejo.

Hasil evaluasi selama dua tahun terakhir menunjukkan rendahnya jumlah peserta didik baru, memotivasi penulis melakukan sosialisasi dengan "Strategi Campaign Melalui Seni Campursari "Siswo Laras Budoyo" Sebagai Upaya Mengembangkan Kepedulian Masyarakat Bagi Pendidikan 
Khusus. Bentuk sosialisasinya dengan menyajikan bukti langsung berupa unjuk keterampilan siswa, pameran karya siswa, dan pentas langsung peserta didik yang tergabung dalam kelompok seni campursari “Siswo Laras Budoyo” dari SLB Negeri Kalirejo.

Sasaran sosialisasi adalah kelompok ibu-ibu anggota Pembinaan Kesejahteraan Keluarga (PKK) yang ada di enam desa yang tersebar di empat kecamatan yaitu Ngraho, Margomulyo, Tambakrejo, dan Ngambon. Alasan pemilihan ibu-ibu anggota PKK sebagai responden karena; 1) ibu-ibu lebih peduli dan paling dekat dengan anak, 2) ibu-ibu lebih banyak bicara untuk menyampaikan kabar baru, 3) ibu-ibu lebih pandai merayu dan mengambil perasaan orang lain termasuk keluarga Anak Berkebutuhan Khusus.

\section{METODE}

Penelitian ini merupakan Penelitian kuantitatif dengan metode eksperimen lebih tepatnya menggunakan One-Group Pretest-Posttest Designs (Sugiyono, 2008:75). Yaitu kelompok subyek diberikan pre tes berupa ceklist sebelum diadakan sosialisasi dan diberikan pos tes berupa ceklist setelah dilakukan sosialisasi.

Penelitian ini dilakukan untuk menemukan gagasan yang kemudian diterapkan dalam upaya perbaikan praktik pengelolaan sekolah. Dalam penelitian tindakan ini menerapkan strategi yang baru yaitu strategi Campaign untuk mengembangkan kepedulian masyarakat tentang pentingnya pendidikan khusus dalam memberikan perubahan ke arah perbaikan dan mutu sekolah.

Subyek dalam penelitian ini adalah 60 responden terdiri atas ibu-ibu anggota Pembinaan Kesejahteraan Keluarga (PKK) dari 6 desa pada 4 kecamatan di Bojonegoro. Tempat penelitian di desa Meduri, Geneng, Tambakrejo, Gading, Kalirejo, dan Bondol. Waktu pelaksanaan kegiatan bulan Oktober sampai Desember 2018.

Pengumpulan data dilakukan melalui ceklist. Ceklist diberikan kepada 60 responden dari 6 desa. Pemberian ceklist dilakukan 2 kali, ceklist yang pertama diberikan sebelum proses sosialisasi dan ceklist kedua diberikan setelah selesai sosialisasi. Ceklist berisi pandangan dan pendapat masyarakat tentang pendidikan khusus dan kualitas SLB Negeri Kalirejo.

\section{HASIL DAN PEMBAHASAN}

Dengan menerapkan Strategi Campaign Melalui Pentas Seni Campursari "Siswo Laras Budoyo” dapat Mengembangkan Kepedulian Masyarakat Tentang Pentingnya Sekolah Bagi Anak Berkebutuhan Khusus di Bojonegoro. Terbukti respon masyarakat sangat baik terhadap karya dan keterampilan peserta didik SLBN Kalirejo.

\section{Hasil}


Setelah kegiatan sosialisasi di 6 desa dengan menerapkan Strategi Campaign Melalui Pentas Seni Campursari “Siswo Laras Budoyo” dan menyebarkan cek list maka hasilnya sebagai berikut:

1. Adanya Peningkatan kepedulian masyarakat terhadap pentingnya sekolah bagi ABK.

Bukti dari keberhasilan program ini adalah 1) beberapa orang tua/wali Anak Berkebutuhan Khusus mulai berdatangan ke sekolah untuk berkonsultasi tentang kondisi anaknya, selama bulan Oktober sampai Desember ada 4 tamu sekolah yang berasal dari orang tua/wali Anak Berkebutuhan Khusus, dibandingkan tahun-tahun sebelumnya tidak pernah ada tamu dari masyarakat untuk berkonsultasi, 2) hasil cek list yang menunjukkan adanya peningkatan kepedulian masyarakat terhadap pentingnya pendidikan untuk Anak Berkebutuhan Khusus yaitu ada peningkatan dari 12 orang naik menjadi 36 orang dari 60 responden. Sehingga terjadi peningkatan $200 \%$ pendapat masyarakat yang peduli terhadap pendidikan bagi Anak Berkebutuhan Khusus.

2. Adanya peningkatan kepercayaan masyarakat terhadap kualitas SLB Negeri Kalirejo.

Hal ini dapat dibuktikan dengan 1) pada saat strategi Campaign melalui pentas seni campursari "Siswo Laras Budoyo" berlangsung terdapat banyak ibu anggota PKK yang minta lagu bahkan ikut menyanyi menghibur audien, memberi uang saweran, dan memberi ucapan selamat kepada tim campursari "Siswo Laras Budoyo", 2) banyaknya permintaan untuk tampil menghibur setelah acara kampanye , 3) meningkatnya jumlah calon peserta didik selama dan setelah kampanye yaitu ada 13 calon peserta didik yang sudah mendaftar untuk tahun pelajaran 2019/2020. Dibandingkan dengan kondisi penerimaan peserta didik baru yang terjadi selama 3 tahun terakhir tertinggi hanya 3 siswa, maka setelah menerapkan Strategi Campaign Melalui Pentas Seni Campursari "Siswo Laras Budoyo” jumlah peserta didik baru tahun pelajaran 2019/2020 akan meningkat 300\%, 4) hasil cek list tingkat kepercayaan masyarakat terhadap kualitas SLB Negeri Kalirejo meningkat dari 12 orang menjadi 30 orang atau naik $150 \%$.

\section{Dampak}

Kegiatan sosialisasi dengan menerapkan Strategi Campaign Melalui Pentas Seni Campursari "Siswo Laras Budoyo" sangat berdampak terhadap pentingnya pendidikan khusus juga keberlangsungan SLB Negeri Kalirejo. Beberapa dampak dari kegiatan ini adalah sebagai berikut; 1. Tersebar luas pentingnya pendidikan untuk Anak Berkebutuhan Khusus (ABK).

Strategi kampanye yang dilaksanakan keliling di 6 desa dari 4 kecamatan dapat mendekatkan sumber informasi dengan penerima informasi secara langsung. Apalagi sebagai penerima informasi adalah ibu-ibu anggota PKK yang sangat mudah dan dengan sukarela menyebarkan informasi pentingnya sekolah bagi Anak Berkebutuhan Khusus. Testimoni yang mereka saksikan melalui tampilan seni campursari menjadi bahan utama untuk disampaikan kepada sanak saudara, 
tetangga, teman, bahkan orang lain yang mereka temui termasuk keluarga Anak Berkebutuhan Khusus. Sehingga tersebar luas pentingnya pendidikan untuk Anak Berkebutuhan Khusus (ABK).

2. Tersebar luas informasi bahwa ABK yang bersekolah mampu berkarya dan berprestasi.

Penampilan kelompok seni campursari "Siswa Laras Budoyo" menjadi salah satu bukti bahwa Anak Berkebutuhan Khusus yang belajar di SLB Negeri Kalirejo telah mendapatkan pendidikan serta latihan untuk mengembangkan kecakapan hidup sehingga mampu berkarya dan berprestasi. Informasi ini akan tersebar luas ke pelosok desa di 4 kecamatan melalui jasa ibu-ibu anggota PKK yang menyaksikan pentas seni tersebut. Kabar ini akan mampu mempengaruhi pola pikir masyarakat terutama para orang tua Anak Berkebutuhan Khusus bahwa Anak Berkebutuhan Khusus yang mendapatkan pendidikan serta pelatihan akan mampu berkarya dan berprestasi.

3. Menambah rasa percaya diri siswa SLBN Kalirejo dalam kegiatan pertunjukkan di depan umum. Dengan menerapkan Strategi Campaign Melalui Pentas Seni Campursari “Siswo Laras Budoyo” yang dilaksanakan keliling di 6 desa pada 4 kecamatan juga menjadi sumber ilmu bagi tim campursari untuk berliterasi. Mereka menimba ilmu dari kekurangannya menguasai musik dan lagu, variasi jenis musik dan lagu, informasi lagu baru, dan yang lebih penting bahwa kegiatan ini menempa dirinya untuk lebih percaya diri di hadapan banyak orang dengan karakter serta gaya yang berbeda.

4. SLB Negeri Kalirejo dikenal masyarakat luas.

Kegiatan kampanye keliling di 6 desa pada 4 kecamatan yang disertai unjuk karya siswa SLB Negeri Kalirejo membuat kesan mendalam di hati masyarakat. Selain di 4 kecamatan tersebut di atas banyak permintaan dari lembaga lain yang ada di Bojonegoro maupun di sekitar kecamatan Ngraho mengundang kelompok seni campursari "Siswo Laras Budoyo" untuk menghibur, diantaranya diundang dalam acara 1) peringatan HUT Kemerdekaan RI ke-73 bertempat di lapangan kecamatan Ngraho, 2) Jamboree Pramuka ranting Ngraho bertempat di bumi perkemahan desa Payaman, 3) HUT Dharmawanita Persatuan ke-19 Cabang Dinas Pendidikan Wilayah kabupaten Bojonegoro bertempat di gedung pertemuan SMKN 4 Bojonegoro, 4) serah terima jabatan Kepala Cabang Dinas Pendidikan wilayah Bojonegoro di gedung pertemuan SMAN 2 Bojonegoro, 5) penutupan program Kuliah Kerja Nyata (KKN) Institut Agama Islam Sunan Giri Bojonegoro bertempat di halaman desa Kalirejo. Pada kesempatan tersebut penulis selalu menyampaikan visi dan misi serta program unggulan SLB Negeri Kalirejo.

\section{Pembahasan}

Kegiatan sosialisasi kami lakukan dengan Strategi Campaign Melalui Pentas Seni Campursari "Siswo Laras Budoyo" di 6 desa. Sasaran kegiatan ini yaitu ibu-ibu anggota Pembinaan 
Strategi Campaign Melalui Seni Campursari "Siswo Laras Budoyo" Sebagai Upaya Mengembangkan

Kepedulian Masyarakat Bagi Pendidikan Khusus Di Kabupaten Bojonegoro

Sutras

Kesejahteraan Keluarga (PKK) yang sedang melakukan arisan dan rapat pembinaan. Kegiatan ini bertujuan supaya warga masyarakat melihat, mendengarkan, membuktikan, dan berpartisipasi aktif dengan menyanyi bersama iringan musik dari siswa SLB Negeri Kalirejo.

Ini kami lakukan supaya warga masyarakat percaya terhadap kemampuan Anak Berkebutuhan Khusus yang mendapat pendidikan di SLB Negeri Kalirejo. Selanjutnya ibu-ibu yang hadir akan menyebarluaskan berita ini ke banyak orang termasuk menggugah hati para orang tua dari Anak Berkebutuhan Khusus supaya peduli terhadap pentingnya pendidikan. Dan bagi ibu orang tua Anak Berkebutuhan Khusus yang kebetulan juga hadir dalam acara ini, harapannya mereka tergerak hatinya dan selanjutnya ada impian supaya anaknya juga bisa meniru dari apa yang ditampilkan oleh siswa SLB Negeri Kalirejo.

Hal ini sejalan dengan pendapat Albert Bandura dalam Mohammad Asrori (2007: h. 23) dalam teori belajar sosial (social learning theory) yang berpandangan bahwa individu dalam mengembangkan tingkah laku positif dilakukan dengan meniru tingkah laku yang diterima masyarakat (socially accepted behavior). Harapannya semakin banyak ibu-ibu yang menyaksikan dan berpartisipasi dalam kegiatan pentas seni (sosialisasi) maka akan lebih cepat tersebar informasi potensi SLB Negeri Kalirejo serta pentingnya sekolah bagi Anak Berkebutuhan Khusus.

Manfaat lain dari kegiatan sosialisasi sebagai pembelajaran di luar kelas sebagai berikut.

1. Memanusiakan manusia (dalam proses pembelajaran guru memperlakukan para siswanya sesuai dengan kondisi dan karakteristik mereka masing-masing. John P. Miller (dalam Hamid 2011;46) menyatakan bahwa pendidikan yang memanusiakan siswa akan selalu terfokus pada pengembangan model pendidikan efektif yang dalam kosa kata Indonesia disebut pendidikan kepribadian atau pendidikan nilai.

2. Meningkatkan motivasi belajar siswa

Dengan kegiatan sosialisasi ternyata menambah percaya diri Anak Berkebutuhan Khusus untuk tampil di depan masyarakat umum serta menambah motivasi untuk belajar lebih baik supaya dapat lebih layak di depan masyarakat.

3. Menumbuhkan rasa senang dalam belajar

Dengan kegiatan sosialisasi menambah rasa senang dan mengurangi kepenatan belajar di dalam kelas.

4. Siswa menjadi lebih aktif dalam belajar

Menurut penulis kegiatan pentas seni campursari dengan berkeliling di 4 kecamatan juga sebagai strategi pembelajaran JAS (Jelajah Alam Sekitar) karena peserta didik menjelajahi 
berbagai jenis kelompok masyarakat dengan kebiasaan yang berbeda-beda. Perbedaan mulai dari cara menyambut tamu, cara menanggapi, permintaan lagu, menyanyi, bahkan cara menyampaikan pertanyaan serta usul kepada penulis. Sehingga strategi pembelajaran ini lebih bersifat student centered yang mendorong peserta didik untuk aktif mencari pengetahuan, mengingat jenis lagu dan nada, serta menambah percaya diri menghadapi berbagai karakter penonton.

Menurut Husamah (dalam Erwin Widiasworo 2017:141), pendekatan pembelajaran JAS menekankan pada kegiatan pembelajaran yang dikaitkan dengan situasi dunia nyata sehingga selain dapat membuka wawasan berpikir yang beragam dari seluruh peserta didik, pendekatan ini memungkinkan peserta didik dapat mempelajari berbagai konsep dan cara mengaitkannya dengan dunia nyata sehingga hasil belajarnya lebih berdaya guna.

Siswa lebih aktif mengembangkan bakat dan keterampilannya karena setelah melakukan sosialisasi mereka semakin tahu kelemahan dan kelebihannya serta peluang yang harus ditangkap di masyarakat umum.

5. Menumbuhkan kreativitas siswa

Melalui kegiatan sosialisasi dengan strategi kampanye juga memberi kesempatan siswa untuk berliterasi yaitu dengan mendapatkan pengalaman lebih banyak setelah berhadapan langsung dengan masyarakat. Dengan banyaknya permintaan lagu dari pemirsa, menyanyi bersama, dan variasi jenis lagu membuat siswa semakin percaya diri tampil di hadapan khalayak ramai.

6. Dapat menerapkan budaya atau keunggulan lokal yang lain

Menurut Albert Bandura dalam Chairul Anwar (2017:103), bahwa kondisi lingkungan sekitar sangat berpengaruh terhadap perilaku seseorang. Lingkungan memberikan posisi yang besar dalam kehidupan sosial sehari-hari, sehingga lingkungan tersebut dapat membentuk kepribadian seseorang. Lebih lanjut menurut Bandura dalam Chairul Anwar (2017:103), antara behavioral, environment, dan perception memberikan andil dalam proses pembelajaran sosial individu. Sebab sesuatu yang dipikirkan individu mempengaruhi perilaku orang tersebut, dan perilaku orang tersebut akan menimbulkan reaksi dari orang lain. Dampak dari kegiatan sosialisasi ini juga ingin membangun persepsi orang-orang yang menontonnya bahkan tetangga, saudara, dan teman dari penonton pentas seni campursari akan mendapat cerita yang akhirnya terbangun persepsi positif terhadap kemampuan siswa berkebutuhan khusus.

\section{KESIMPULAN}

Berdasarkan hasil analisis dan pembahasan yang dilakukan penulis, maka dapat disimpulkan sebagai berikut; 
1. Adanya Peningkatan kepedulian masyarakat terhadap pentingnya sekolah bagi Anak Berkebutuhan Khusus. Hasil cek list yang menunjukkan adanya peningkatan kepedulian masyarakat terhadap pentingnya pendidikan untuk Anak Berkebutuhan Khusus sebesar 300\%, yaitu ada peningkatan dari 12 orang naik menjadi 36 orang dari 60 responden.

2. Adanya peningkatan kepercayaan masyarakat terhadap kualitas SLB Negeri Kalirejo, hasil cek list menunjukkan kenaikan $150 \%$ yaitu dari semula 12 orang meningkat menjadi 30 orang.

Supaya lebih bermanfaat dari hasil penelitian ini maka saran penulis bagi sekolah dan bagi guru adalah sebagai berikut:

1. Sekolah harus mampu menggali bakat dan prestasi peserta didik baik akademik maupun non akademik.

2. Melakukan sosialisasi pentingnya sekolah bagi Anak Berkebutuhan Khusus secara periodik dan inovatif.

3. Sekolah harus bekerjasama dengan masyarakat untuk meningkatkan kualitas layanan pendidikan.

4. Kepercayaan masyarakat (stake holder) terhadap sekolah harus selalu dijaga bahkan ditingkatkan sebagai wujud sinergitas antara sekolah, masyarakat, dan pemerintah dalam meningkatkan mutu pendidikan di Indonesia.

5. Guru harus meningkatkan pengetahuan pembelajaran di dalam kelas dan di luar kelas.

6. Guru harus kreatif dan inovatif dalam pembelajaran.

\section{DAFTAR PUSTAKA}

Anonim. (2011) Kepimpinan Pembelajaran, Bahan ajar diklat calon kepala sekolah LPMP Provinsi Jawa Timur.

Anonim. (2011) Kewirausahaan, Bahan ajar diklat kepala sekolah LPMP Provinsi Jawa Timur.

Ardiansyah, M.A. (2011), Kepemimpinan Transformasional

Arief Rahman. (2015) Guru, Penerbit Erlangga, Jakarta.

Chairul Anwar, M.Pd.(2017), Teori-teori Pendidikan Klasik Hingga Kontemporer, IRCiSoD, Yogjakarta.

Bojonegorokab.go.id. _. Demografi Kabupaten Bojonegoro. Diakses tanggal 28 Desember 2017, dari http://www.bojonegorokab.go.id/demografi

Erwin Widiasworo. 2017, Strategi \& Metode Mengajar Siswa di Luar Kelas, Ar-ruzz Media, Yogyakarta.

Hudi Winarso (dekan Fakultas Kedokteran Universitas Ciputra Surabaya) Jawa Post 11 Januari 2018) 
Khoiri, dkk. 2012. Laporan diklat calon kepala sekolah Kabupaten Bojonegoro.

Moh. Sholeh Hamid, S.Pd. 2011, Metode Edutainment, Diva Press, Yogjakarta.

Mohammad Asrori, M.Pd. 2008, Psikologi Pembelajaran, CV. Wacana Prima, Bandung.

Permendiknas No. 13 tahun 2017 tentang Standar Kepala Sekolah/Madrasah

Permendibud No. 6 Tahun 2018 tentang Penugasan guru sebagai Kepala Sekolah

Permendibud No. 15 Tahun 2018 tentang Beban Kerja Guru, Kepala Sekolah, dan Pengawas Sekolah.

Soetjiningsih 1995, Tumbuh Kembang Anak, Penerbit Buku Kedokteran, Jakarta.

Sutjihati Somantri 2006, Psikologi Anak Luar Biasa, PT. Refika Aditama. Bandung.

Sugiyono 2008, Metode Penelitian Kuantitatif Kualitatif dan $R \& D$, Alfabeta, Bandung.

Undang-undang RI No. 20 Tahun 2003 tentang Sistem Pendidikan Nasional.

Yustiono, E. 2011. Kepemimpinan Transformasional. Diakses tanggal 28 Juni 2016, dari http://www.stialanbandung.ac.id. 